\title{
Pengaruh Kualitas Pelayanan, Kewajiban Moral, Sanksi Pajak dan Tapping Box pada Kepatuhan Wajib Pajak Hotel
}

\author{
Ni Putu Mitha Pratiwi ${ }^{1}$ \\ Ni Ketut Lely Aryani \\ ${ }^{1,2}$ Fakultas Ekonomi dan Bisnis Universitas Udayana (Unud), Bali, Indonesia \\ e-mail: mithapratiwi3@gmail.com
}

\begin{abstract}
ABSTRAK
Tujuan dari penelitian ini adalah untuk mengetahui pengaruh kualitas pelayanan, kewajiban moral, sanksi pajak dan penerapan alat perekam transaksi (Tapping Box) pada kepatuhan wajib pajak hotel di Badan Pengelolaan Keuangan dan Aset Daerah Kabupaten Gianyar. Penelitian ini dilakukan pada semua hotel yang telah di pasangkan alat tapping box yang tersebar di Kabupaten Gianyar. Teknik analisis data yang digunakan adalah analisis regresi linear berganda. Berdasarkan hasil penelitian, penelitian ini menunjukkan bahwa variabel kualitas pelayanan, kewajiban moral, sanksi pajak, dan penerapan alat perekam transaksi (Tapping Box) berpengaruh positif pada kepatuhan wajib pajak dalam membayar pajak hotel di di Badan Pengelolaan Keuangan dan Aset Daerah Kabupaten Gianyar. Artinya, semakin baik kualitas pelayanan, kewajiban moral, sanksi pajak, dan penerapan alat Tapping box akan mendorong wajib pajak untuk memenuhi kewajiban perpajakannya.

Kata kunci: Kualitas pelayanan, kewajiban moral, sanksi pajak, tapping box
\end{abstract}

\begin{abstract}
The purpose of this study was to determine the effect of service quality, moral obligations, tax sanctions and the application of transaction recording devices (Tapping Box) on hotel taxpayer compliance at the Regional Financial and Asset Management Agency of Gianyar Regency. This research was conducted at all hotels that have been installed by tapping box devices that are spread in Gianyar Regency. The data analysis technique used is multiple linear regression analysis. Based on the results of the study, this study shows that service quality variables, moral obligations, tax sanctions, and the application of transaction recording devices (Tapping Box) have a positive effect on taxpayer compliance in paying hotel taxes at the Regional Financial and Asset Management Agency of Gianyar Regency. This means that the better quality of service, moral obligations, tax sanctions, and the application of transaction recording devices (Tapping Boxes) will encourage taxpayers to fulfill their tax obligations.
\end{abstract}

Keywords: Service quality, moral obligation, tax sanction, tapping box

\section{PENDAHULUAN}

Undang-undang No. 32 tahun 2004 tentang Pemerintahan Daerah adalah salah satu landasan yuridis bagi pengembangan otonomi daerah di Indonesia. UndangUndang menyebutkan bawha pengembangan otonomi pada daerah Kabupaten dan Kota diselenggarakan dengan memperhatikan prinsip-prinsip demokrasi, peran serta masyarakat, pemerataan, keadilan, serta potensi dan keanekaragaman daerah. 
Ni Putu Mitha Pratiwi dan Ni Ketut Lely Aryani. Pengaruh...

Sistem pemerintahan yang bersifat otonomi di Indonesia, memberikan kewenangan kepada pemerintah daerah untuk mengatur sendiri daerah yang dipimpinnya untuk memajukan dan mengembangkan potensi daerahnya. Pajak daerah dan retribusi daerah merupakan salah satu bentuk peran serta masyarakat dalam penyelenggaraan otonomi daerah (Chritina \& Kepramareni, 2012) Sistem pemerintahan otonomi daerah diharapkan dapat membantu peningkatan pemerataan pembangunan di seluruh wilayah di Indonesia sehingga pembangunan nasional di Indonesia akan berjalan dengan baik. Untuk meningkatkan pembangunan tersebut dibutuhkan biaya yang tidak sedikit jumlahnya (Anggraini, 2012).

Pemerintah dalam hal ini harus cermat memanfaatkan dana yang tersedia. Salah satu sumber penerimaan pemerintah adalah dari sektor pajak. Menurut Undang-Undang nomor 28 Tahun 2009 Tentang Pajak Daerah dan Retribusi Daerahyang mengatur tentang Pajak Daerah dan Retribusi Daerah menetapkan jenis pajak kabupaten/kota terdiri atas pajak hotel, pajak restoran, pajak hiburan, pajak reklame, pajak penerangan jalan, pajak mineral bukan logam dan batuan, pajak parkir, pajak air tanah, pajak bumi dan bangunan perdesaan dan perkotaan, dan bea perolehan ha katas tanah dan bangunan. Pajak hotel di Kabupaten Gianyar merupakan salah satu pajak daerah, hasil dari penerimaan pajak tersebut digunakan oleh Pemerintah Kabupaten Gianyar untuk membiayai dan meningkatkan pelayanan kepada masyarakat di Kabupaten Gianyar. Pajak hotel untuk Kabupaten Gianyar diatur dalam PERDA Kabupaten Gianyar UndangUndang Nomor 2 Tahun 2011 Tentang Pajak Hotel Kabupaten Gianyar. Pajak 
hotel merupakan bagian dari pajak daerah yang juga memberikan kontribusi yang cukup besar terhadap penerimaan pajak Kabupaten Gianyar. Pajak hotel adalah pajak yang secara tidak langsung dibayarkan oleh masyarakat yang menikmati pelayanan di hotel kepada pemerintah melalui hotel yang bersangkutan

Pada Tabel 1 disajikan jumlah wajib pajak hotel yang terdaftar di Badan Pendapatan Kota Denpasar.

Tabel 1.

Perkembangan Pendaftaran Wajib Pajak Hotel PadaBadan Pendapatan Kota DenpasarTahun 2013-2017(Dalam Unit)

\begin{tabular}{ccccccc}
\hline Tahun & $\begin{array}{c}\text { Hotel } \\
\text { Berbintang }\end{array}$ & $\begin{array}{c}\text { Kotel } \\
\text { Melati }\end{array}$ & $\begin{array}{c}\text { Pondok } \\
\text { Wisata }\end{array}$ & Villa & Cottages & Jumlah \\
\hline 2013 & 7 & 13 & 16 & 9 & 1 & 46 \\
2014 & 6 & 11 & 15 & 7 & 0 & 39 \\
2015 & 5 & 9 & 14 & 1 & 0 & 29 \\
2016 & 1 & 2 & 6 & 0 & 2 & 11 \\
2017 & 0 & 4 & 3 & 3 & 0 & 10 \\
\hline
\end{tabular}

Sumber: Data diolah, 2018

Berdasarkan Tabel 1 jumlah wajib pajak hotel yang terdaftar di Badan Pendapatan Kota Denpasar dari tahun 2013-2017 mengalami penurunan. Dibandingkan dengan Tabel 1.2 dimana jumlah wajib pajak hotel yang terdaftar di Badan Pengelolaan Keuangan dan Aset Daerah Kabupaten Gianyar dari tahun 20132017 mengalami fluktuasi. Jumlah wajib pajak hotel yang terdaftar di pada tahun 2017 di Badan Pendapatan Kota Denpasar lebih kecil dari Badan Pengelolaan Keuangan dan Aset Daerah Kabupaten Gianyar hanya berjumlah 10 wajib hotel sebaliknya pada tahun 2017 jumlah wajib pajak hotel yang terdaftar di Badan Pengelolaan Keuangan dan Aset Daerah Kabupaten Gianyar lebih besar yakni 42 wajib pajak. Hal ini disebabkan oleh pesatnya perkembangan sektor pariwisata 
Ni Putu Mitha Pratiwi dan Ni Ketut Lely Aryani. Pengaruh...

Kabupaten Gianyar dan tingginya jumlah kunjungan wisatawan serta meningkatnya jumlah penyediaan fasilitas penginapan. Terjadinya Penurunan jumlah wajib pajak hotel di Badan Pendapatan Daerah Kota Denpasar dikarenakan penutupan usaha hotel di Kota Denpasar yang cukup signifikan. Terjadinya peningkatan wajib pajak hotel di Kabupaten Gianyar setiap tahunnya tidak langsung memberikan efek yang positif bagi penerimaan pajak daerah apabila kesadaran untuk membayar pajak tidak meningkat.

Tabel 2.

Perkembangan Pendaftaran Wajib Pajak Hotel PadaBadan Pengelolaan Keuangan Dan Aset Daerah Kabupaten Gianyar Tahun 2013-2017 (Dalam Unit)

\begin{tabular}{ccccccc}
\multicolumn{7}{c}{ Unit) } \\
Tahun & $\begin{array}{c}\text { Hotel } \\
\text { berbintang }\end{array}$ & $\begin{array}{c}\text { Kotel } \\
\text { Melati }\end{array}$ & $\begin{array}{c}\text { Hotel Wisata } \\
\text { Hilla }\end{array}$ & Cottages & Jumlah \\
\hline 2013 & 0 & 4 & 50 & 36 & 0 & 90 \\
2014 & 0 & 0 & 0 & 1 & 0 & 1 \\
2015 & 12 & 104 & 384 & 183 & 1 & 684 \\
2016 & 6 & 39 & 76 & 76 & 1 & 198 \\
2017 & 0 & 5 & 28 & 9 & 0 & 42 \\
\hline
\end{tabular}

Sumber: Data diolah, 2018

Sesuai dengan ketentuan Undang-Undang nomor 28 Tahun 2009 Tentang Pajak Daerah dan Retribusi Daerah, maka sejak tahun 2013 Badan Pengelolaan Keuangan Dan Aset Daerah Kabupaten Gianyar mulai menerapkan sistem selfassessment dalam penetapan pajak hotel. Setelah diterapkannya self-assessment wajib pajak cenderung memanfaatkan kepercayaan yang telah diberikan hal tersebut masih dapat dilihat dari adanya tunggakan pajak hotel. Jumlah tunggakan pajak hotel diBadan Pengelolaan Keuangan Dan Aset Daerah Kabupaten Gianyar dan Badan Pendapatan Kota Denpasar dapat dilihat pada Tabel 3berikut. 
Tabel 3.

Tunggakan Pajak Hotel Di Badan Pendapatan Kota Denpasar dan BadanPengelolaan Keuangan Dan Aset Daerah Kabupaten GianyarTahun 2013-2017 (Dalam Ribuan)

\begin{tabular}{ccc} 
Tahun & $\begin{array}{c}\text { Tunggakan Wajib Pajak Kota } \\
\text { Denpasar }\end{array}$ & $\begin{array}{c}\text { Tunggakan Wajib Pajak Kabupaten } \\
\text { Gianyar }\end{array}$ \\
\hline 2013 & $2,299,525,217.49$ & $8,482,662,546.70$ \\
2014 & $3,226,343,034.10$ & $7,767,758,121.17$ \\
2015 & $3,805,970,048.26$ & $8,535,955,250.82$ \\
2016 & $5,357,536,789.26$ & $18,807,536,326.24$ \\
2017 & $8,363,783,320.96$ & $29,737,501,413.13$ \\
\hline
\end{tabular}

Berdasarkan Tabel 3 tunggakan pajak hotel di Kota Denpasar dan Kabupaten Gianyar mengalami peningkatan dari tahun 2013 sampai dengan 2017, akan tetapi tunggakan wajib pajak hotel di Kabupaten Gianyar lebih besar dibandingkan dengan Kota Denpasar, hal ini disebabkan oleh faktor ekonomi pasca krisis ekonomi yang melanda perekonomian Indonesia. Tunggakan pajak hotel juga disebabkan oleh masih rendahnya kewajiban moral wajib pajak hotel dapat dilihat adanya tunggakan yang cukup besar, adanya pemeriksaan kepada wajib pajak yang tidak benar dalam pengisian Surat Pemberitahuan Pajak Daerah (SPTPD) atau karena ditemukannya data fisik yang tidak dilaporkan oleh wajib pajak, adanya sanksi pajak, dan wajib pajak yang tidak mampu membayar kewajiban perpajakannya.

Adanya tunggakan pajak menandakan bahwa wajib pajak belum semua patuh akan kewajibannya membayar pajak hotel yang dikelola dan mengindikasikan bahwa menurunnya kewajiban moral wajib pajak hotel .Menurut (Torgler, 2005) salah satu masalah yang besar dan serius bagi para pembuat dan pengamat kebijakan ekonomi adalah meningkatkan kepatuhan wajib pajak. Kepatuhan dalam wajib pajak dapat dikatakan sebagai kepatuhan 
Ni Putu Mitha Pratiwi dan Ni Ketut Lely Aryani. Pengaruh...

dalam persyaratan pelaporan pajak dimana wajib pajak mengajukan dan melaporkan kewajibannya sesuai dengan peraturan yang berlaku (Devos \& Zackrisson, 2015). Kepatuhan perpajakan pada prinsipnya adalah tindakan wajib pajak dalam memenuhi kewajiban perpajakannya sesuai dengan ketentuan peraturan perundang-undangan dan peraturan pelaksanaan perpajakan yang berlaku dalam suatu negara dalam (Tripuspitasari, 2012 dalam Pratiwi \& Setiawan, 2014). Mengingat kepatuhan merupakan faktor penting penerapan self assessment system dalam peningkatan penerimaan pajak, maka perlu secara intensif dikaji tentang faktor-faktor yang memengaruhi kepatuhan wajib pajak. Ada beberapa faktor yang terkait dengan tingkat kepatuhan wajib pajak dalam melaksanakan kewajibannya.

Faktor pertama pelayanan berkualitas dimana pelayanan adalah suatu hal yang penting nantinya akan dapat meningkatkan kepatuhan wajib pajak. Kualitas pelayanan yang baik merupakan salah satu upaya dalam meningkatkan kepatuhan wajib pajak. Kualitas pelayanan petugas yang baik diharapkan dapat meningkatan kepuasan wajib pajak sehingga meningkatkan kepatuhan dalam memenuhi kewajiban perpajakannya. Pelayanan petugas yang baik akan memberikan kenyamanan bagi wajib pajak. Salah satu upaya yang dapat dilakukan guna meningkatkan kualitas pelayanan yaitu dengan menyediakan sarana-prasarana maupun sistem informasi terutama dalam pembentukan perilaku petugas yang siap melayani masyarakat selaku wajib pajak (Nirajenani \& Merkusiwati, 2018). Hasil penelitian (Pranata \& Setiawan, 2015) menunjukan kualitas pelayanan berpengaruh positif pada kepatuhan wajib pajak dalam 
membayar pajak restoran di Dinas Pendapatan Kota Denpasar. Hasil penelitian tersebut sejalan dengan penelitian (Nirajenani \& Merkusiwati, 2018) menunjukan bahwa kualitas pelayanan berpengaruh positif dan signifikan terhadap kepatuhan wajib pajak dan semakin tinggi kualitas pelayanan maka wajib pajak semakin patuh, semakin rendah kualitas pelayanan maka wajib pajak semakin tidak patuh dalam membayar pajak.

Tinggi rendahnya kepatuhan pajak juga dipengaruhi oleh faktor yang kedua adalah kewajiban moral, etika prinsip hidup dan perasaan bersalah merupakan kewajiban moral yang dimiliki oleh setiap orang dalam melaksanakan kewajiban perpajakannya dalam hal ini untuk kepatuhan wajib pajak dalam membayar pajak hotel. Kewajiban moral pajak yang diukur bukan individunya, namun lebih kepada sikap dan pendirian individu. Sikap dan pendirian individu ini lebih menyentuh pada sisi kesadaran seorang individu dalam melaksanakan kewajibannya. Hal ini dapat dilihat sebagai kewajiban moral untuk membayar pajak, keyakinan untuk berkontribusi kepada masyarakat dengan membayar pajak ( Akib \&Sari, 2017). Penelitian yang dilakukan oleh (Daniel \& Wong, 2012) dimana tingkat kepatuhan pajak akan menjadi lebih tinggi ketika wajib pajak memiliki kewajiban moral yang lebih kuat. Hasil Penelitian tersebut sejalan dengan penelitian (Dewi \& Sukartha, 2015) dimana kewajiban moral berpengaruh positif pada kepatuhan wajib pajak dalam membayar pajak hotel.

Tinggi rendahnya kepatuhan wajib pajak juga dapat dipengaruhi oleh faktor yang ketiga yakni sanksi pajak. Sanksi pajak menjadi pagar pembatas yang nyata dalam pelaksanaan suatu peraturan, yang bermaterikan hak dan 
Ni Putu Mitha Pratiwi dan Ni Ketut Lely Aryani. Pengaruh...

kewajiban. Sanksi ialah wujud dari pelanggaran atas hak suatu pihak atau tidak dipenuhinya kewajiban yang telah ditentukan berdasarkan undang - undang maupun peraturan turunannya (Dewi \& Merkusiwati, 2018). Terjadinya tunggakan wajib pajak hotel tahun 2013-2017 cukup tinggi. Tunggakan tersebut terjadi karena adanya wajib pajak yang tidak patuh dalam melaksanakan kewajibannya sehingga diperlukan adanya peraturan yang lebih tegas guna meningkatkan pendapatan Negara berupa sanksi perpajakan. Sanksi pajak memiliki peran penting guna memberikan pelajaran bagi pelanggar pajak agar tidak meremehkan peraturan perpajakan (Yasa \& Jati, 2017). Sanksi yang dikenakan berupa sanksi administrasi dan sanksi pidana. Sanksi perpajakan dapat diberikan kepada wajib pajak yang terlambat menyelesaikan kewajibannya dan juga kepada wajib pajak yang melaporkan pajak terutangnya secara tidak benar sesuai dengan jumlah yang seharusnya (Jaya \& Jati, 2016). Hasil penelitian yang dilakukan (Susilawati \& Budiartha, 2013) menyatakan bahwa sanksi pajak berpengaruh positif pada kepatuhan wajib pajak dalam membayar Pajak Kendaraan Bermotor. Hasil penelitian tersebut sejalan dengan penelitian (Putra \& Merkusiwati, 2018) hasil Penelitian semakin wajib pajak mengetahui dan mentaati sanksi perpajakan yang diterapkan sesuai dengan peratuan perundangundangan yang berlaku maka kepatuhan wajib pajak dalam melaksanakan kegiatan perpajakkannya akan meningkat.

Tinggi rendahnya kepatuhan wajib pajak juga dapat dipengaruhi oleh faktor yang keempat yakni monitoring online dengan menggunakan perangkat Tapping Box. Tapping Box akan menangkap data yang dikirim dari mesin kasir 
ke printer dan kemudian mengirimkan melalui jaringan GSM ke server Badan Pengelolaan Keuangan dan Aset Daerah Kabupaten Gianyar. Aplikasi pengolah data dan pelaporan akan menampilkan laporan rekapan transaksi dan pajaknya secara total maupun masing-masing wajib pajak. Kegiatan pemasangan Tapping Box mulai dilakukan sejak bulan November 2016, sudah 225 wajib pajak hotel yang telah dipasangalat Tapping Boxdi Badan Pengelolaan Keuangan dan Aset Daerah Kabupaten Gianyar. Jika dibandingkan dengan Kota Denpasar pemasangan alat perekam transaksi lebih sedikit jumlahnya yaitu sebesar 35 untuk wajib pajak hotel. Pemasangan alat perekan transaksi (Tapping Box) belum merata kesemua wajib pajak hotel dikarenakan minimnya ketersediaan anggaran dan jumlah SDM yang terbatas (Badan Pengelolaan Keuangan dan Aset Daerah Kabupaten Gianyar, 2018). Menurut (James \& Nobes, 1997)menyatakan bahwa tidak satupun sistem perpajakan dapat berfungsi dengan efektif tanpa peran serta wajib pajak, karena faktor-faktor yang memengaruhi kepatuhan pajak sangat penting.

Penelitian ini dilakukan untuk menguji kembali beberapa faktor yang memengaruhi kepatuhan wajib pajak hotel di Kabupaten Gianyar dan dilakukan karena kepatuhan pembayaran pajak merupakan kunci untuk menjamin keberhasilan pemerintah dalam menghimpun pajak . Penelitian ini bertujuan untuk mengetahui apakah kepatuhan wajib pajak dipengaruhi oleh kulitas pelayanan, kewajiban moral, sanksi perpajakan dan penerapan alat perekam transaksi (Tapping Box). 
Ni Putu Mitha Pratiwi dan Ni Ketut Lely Aryani. Pengaruh...

Kepatuhan wajib pajak dapat dikatakan melalui kualitas pelayanan. Teori Legitimasi jika dikaitkan dengan kualitas pelayanan, dimana pelayanan yang baik adalah pelayanan yang dapat memberikan rasa puas bagi pelanggan yang dalam hal ini wajib pajak hotel. Sehingga dengan memberikan pelayanan yang baik kepada pelanggan dapat meningkatkan kepatuhan wajib pajak. Behavioral beliefs adalah keyakinan individu akan hasil dari suatu perilaku dan evaluasi atas hasil tersebut. Keyakinan akan hasil evaluasi dari suatu perilaku wajib pajak dapat dipengaruhi adanya kualitas pelayanan. Kepatuhan wajib pajak hotel dalam memenuhi kewajibannya dalam membayar pajak salah satunya dipengaruhi bagaimana mutu pelayanan yang diberikan oleh petugas pajak. Petugas pajak diharapkan mampu memberikan pelayanan secara professional, tanggap atas kesulitan yang dihadapi oleh wajib pajak dan ahli dalam bidangnya.

(Boonyarat, Sofian, \& Wadeecharoen, 2015) menyatakan bahwa kualitas pelayanan berpengaruh pada kepatuhan wajib pajak. Harapan dari diberikannya kualitas pelayanan yang baik yaitu wajib pajak dapat memperoleh kemudahan. Pelayanan yang baik dapat membantu wajib pajak saat kesulitan maupun permasalahan terkait perhitungan, penyetoran dan pelaporan yang dilakukan oleh wajib pajak sehingga wajib pajak merasa senang, semakin mengerti dan memahami akan kewajiban pajaknya yang harus dipenuhi. Penelitian yang dilakukan sebelumnya oleh (Sucandra \& Supadmi, 2016). Wajib pajak yang mendapatkan pelayanan dengankualitas yang baik akan senantiasa merasa senang, merasa puas atas pemberian pelayanan yang diberikan petugas pajak karena wajib pajak dapat memperoleh kemudahan dalam menyelesaikan dan melaksanakan 
seluruh hak dan kewajibannya sebagai wajib pajak sehingga kepatuhan wajib pajak dalam memenuhi kewajibannya meningkat. Sejalan dengan penelitian yang telah dilakukan oleh (Layata \& Setiawan, 2014), (Juliantara \& Setiawan, 2017), (Sucahyani \& Sukartha, 2017) menyimpulkan bahwa kualitas pelayanan berpengaruh positif terhadap kepatuhan wajib pajak. Berdasarkan hal tersebut muncul hipotesis yang pertama sebagai berikut.

$\mathrm{H}_{1}$ : Kualitas pelayanan berpengaruh positif pada kepatuhan wajib pajak dalam membayar pajak hotel di Badan Pengelolaan Keuangan dan Aset Daerah Kabupaten Gianyar.

Teori legitimasi jika dikaitkan dengan kewajiban moral, merupakan motivasi yang muncul dari dalam diri individu untuk membayarkan kewajibannyanya. Motivasi dapat muncul dari kewajiban moral wajib pajak untuk berkontribusi kepada Negara dengan membayar pajak. Wajib pajak yang mempunyai moral yang baik akan lebih taat pada aturan perpajakan dan akan mampu meningkatkan tingkat kepatuhannya. Wajib pajak yang lebih menggunakan prinsip moral dalam pengambilan keputusan pembayaran pajak akan lebih patuh dibandingkan dengan wajib pajak lainnya. Untuk itu, setiap wajib pajak yang memiliki kewajiban moral yang baik dengan cara pandang positif tehadap pajak serta menganggap pak itu sebagai suatu kewajiban yang positif maka ini juga akan meningkatkan kepatuhan wajib pajak dalam membayar pajaknya.

Kewajiban moral selalu berkaitan dengan nilai moral yang dimiliki dengan nilai moral yang di miliki oleh individu. Etika, prinsip hidup, perasaan bersalah merupakan kewajiban moral yang dimiliki setiap orang dalam melaksankan sesuatu. Menurut penelitian yang dilakukan (Akib, Sari, \& Asnia, 2017) bahwa 
Ni Putu Mitha Pratiwi dan Ni Ketut Lely Aryani. Pengaruh...

tanggung jawab moral berpengaruh positif dan signifikan terhadap kepatuhan pelaporan wajib pajak badan. Hal ini menunjukkan bahwa tanggung jawab moral dapat mendorong tingkatkepatuhan pelaporan wajib pajak badan. Semakin baik tanggung jawab moralseseorang maka semakin meningkat pula tingkat kepatuhan seseorang dalammemenuhi kewajiban perpajakkannya.Sejalan dengan penelitian yang telah dilakukan oleh (Putri \& Jati, 2015), (Layata \& Setiawan, 2014) dan (Indrayani \& Sukartha, 2014) menunjukan bahwa kewajiban moral berpengaruh positif terhadap kepatuhan wajib pajak.Berdasarkan hal tersebut muncul hipotesis yang kedua sebagai berikut.

$\mathrm{H}_{2}$ : Kewajiban moral berpengaruh positif pada kepatuhan wajib pajak dalam membayar pajak hotel di Badan Pengelolaan Keuangan dan Aset Daerah Kabupaten Gianyar.

Teori legitimasi jika dikaitkan dengan saksi pajak, tidak terlepas dari undang-undang perpajakan. Bagi wajib pajak yang taat dalam menjalankan kewajibannya walaupun tidak mendapatkan penghargaan atau imbalan atas kepatuhannya wajib pajak harus melaksanakan kewajibannya tepat waktu. Wajib pajak akan mendapatkan saksi pajak apabila dengan sengaja tidak memenuhi kewajiban perpajakannya. Theory of Planned Behavior jika dikaitkan dengan sanksi pajak, yaitu berkaitan dengan control belief yang merupakan keyakinan individu tentang hal-hal yang mendukung atau menghambat perilakunya dan persepsinya tentang seberapa kuat hal tersebut memengaruhi perilakunya. Dimana control belief membentuk variabel kontrol yang dipersepsikan (perceivedbehavioral control). Saksi pajak terkait dengan perceivedbehavioral control, sanksi pajak dibuat untuk mendukung agar wajib pajak mematuhi peraturan perpajakan. 
Kepatuhan wajib pajak itu sendiri akan ditentukan berdasarkan persepsi wajib pajak tentang seberapa kuat saksi pajak mampu mendukung perilaku wajib pajak untuk taat terhadap pajak menurut (Sucahyani \& Sukartha, 2018). (Dewi \& Merkusiwati, 2018)menyatakan bahwa Sanksi perpajakan berpengaruh postif terhadap kepatuhan pelaporan wajib pajak. Artinya semakin tegas sanksi yang diberikan akan membuat wajib pajak tersebut semakin patuh untuk memenuhi kewajiban perpajakannya. Sejalan dengan penelitian yang dilakukan oleh(Mentari \& Rahayu, 2015), (Dewi \& Merkusiwati, 2018) menunjukkan bahwa sanksi perpajakan berpengaruh positif terhadap kepatuhan Wajib Pajak hotel. Berdasarkan hal tersebut muncul hipotesis yang ketiga sebagai berikut.

$\mathrm{H}_{3}$ : Sanksi pajak berpengaruh positif pada kepatuhan wajib pajak dalam membayar pajak hotel di Badan Pengelolaan Keuangan dan Aset Daerah Kabupaten Gianyar.

Teori Legitimasi jika dikaitkan dengan pengaruh penerapan tapping box, dimana perusahaan mengarapkan hal yang diinginkan sejalan dengan apa yang diingkan oleh wajib pajak. Dimana dalam hal ini pemasangan alat tapping box diharapkan mampu membantu wajib pajak dalam melaporkan kewajibannya kepada petugas. Control belief merupakan keyakinan individu tentang keberadaan hal-hal yang mendukung atau menghambat perilakunya dan persepsinya tentang seberapa kuat hal-hal tersebut memengaruhi perilakunya. Penetapan pajak hotel berdasarkan self assessment system dimana seringkali menimbulkan terjadinya tindakan dinginkan, sehingga sistem pemungutan self assessment perlu ditunjang dengan sistem monitoring online. Sistem monitoring online yang digunakan di 
Ni Putu Mitha Pratiwi dan Ni Ketut Lely Aryani. Pengaruh...

Badan Pengelolaan Keuangan dan Aset Daerah Kabupaten Gianyar disebut dengan perangkat pemantau transaksi atau yang dikenal dengan Tapping Box.

Penerapan alat perekam transaksi (Tappping Box) sangat efektif didalam mengurangi terjadinya kecurangan terhadap pelaporan pajak. Hal ini karena tapping box mampu memberikan gambaran yang lebih detail terhadap jumlah pajak yang harus dibayarkan oleh wajib pajak dan akan berdampak signifikan terhadap penerimaan pajak daerah menurut (Pramasita \& Resmini, 2018). Menurut penelitian (Pramasita \& Resmini, 2018) penerapan tapping box akan meninggatkan dan berpengaruh positif pada kepatuhan wajib pajak dalam membayar pajak, maka dapat dirumuskan hipotesis sebagai berikut.Berdasarkan hal tersebut muncul hipotesis yang keempat sebagai berikut.

$\mathrm{H}_{4}$ : Penerapan alat perekam transaksi (Tapping Box) berpengaruh positif pada kepatuhan wajib pajak dalam membayar pajak hotel di Badan Pengelolaan Keuangan dan Aset Daerah Kabupaten Gianyar.

\section{METODE PENELITIAN}

Penelitian ini dilakukan di Badan Pengelolaan Keuangan dan Aset Daerah Kabupaten Gianyar yang beralamat di Jl. Ciuang Wanara, Sukawati. Badan Pengelolaan Keuangan dan Aset Daerah Kabupaten Gianyar dipilih sebagai lokasi penelitian karena terdapat jumlah piutang Pajak Hotel dari tahun 2013-2017 yang mengalami peningkatan jumlah piutang. Fenomena ini terjadi karena kurangnya kepatuhan Wajib Pajak Hotel sehingga peneliti tertarik untuk meneliti faktorfaktor yang memengaruhi kepatuhan Wajib Pajak Hotel pada Badan Pengelolaan Keuangan dan Aset Daerah Kabupaten Gianyar. 
Variabel independen yang digunakan dalam penelitian ini adalah kualitas pelayanaan (X1), kewajiban moral (X2), sanksi pajak (X3), dan penerapan alat perekam transaksi (Tapping Box) (X4).Variabel dependen yang digunakan dalam penelitian ini adalah kepatuhan wajib pajak hotel (Y).

Populasi dalam penelitian ini adalah Wajib Pajak Hotel yang terdaftar pada Badan Pengelolaan Keuangan dan Aset Daerah Kabupaten Gianyar dari tahun 2013 sampai dengan tahun 2017, yaitu sejumlah 1.100 Wajib Pajak Hotel yang terdaftar di Badan Pengelolaan Keuangan dan Aset Daerah Kabupaten Gianyar. Teknik pengambilan sampel dalam penelitian ini menggunakan metode Purposive sampling.

Analisis model linear berganda dilakukan untuk mengetahui pengaruh antar variabel terikat dan variabel bebas dengan bantuan Software Statistical Package for Social Science (SPSS) for Windows. Model regresi linear berganda ditunjukkan sebagai berikut.

$$
Y=\alpha+\beta_{1} X_{1}+\beta_{2} X_{2}+\beta_{3} X_{3}+\beta_{4} X_{4}+\varepsilon
$$

Keterangan:

Y : Kepatuhan Wajib Pajak Hotel

$\alpha$ : Konstanta

$\mathrm{X} 1$ : Pengaruh kualitas pelayanan

X2: Kewajiban moral

X3: Sanksi Pajak

X4: Penerapan Alat Perekam Transaksi (Tapping Box)

$\beta 1$ : Koefisien regresi variabel $X_{1}$

$\beta 2$ : Koefisien regresi variabel $X_{2}$

$\beta 3$ : Koefisien regresi variabel $X_{3}$

$\beta 3$ : Koefisien regresi variabel $X_{4}$

$\varepsilon$ : residual 
Ni Putu Mitha Pratiwi dan Ni Ketut Lely Aryani. Pengaruh...

\section{HASIL DAN PEMBAHASAN}

Statistik deskriptif berhubungan dengan pengumpulan dan peringkat data yang menggambarkan karakteristik sampel yang digunakan dalam penelitian ini. Analisis ini berguna memberikan gambaran atau deskripsi suatu data yang dilihat dari besarnya nilai minimum, nilai maksimum, nilai mean dan simpangan baku (standard deviation) dengan $\mathrm{N}$ merupakan banyaknya responden penelitian. Untuk mengukur nilai sentral dari distribusi data dapat digunakan dengan pengukuran rata-rata (mean), sedangkan standar deviasi merupakan perbedaan nilai data yang diteliti dengan nilai rata-rata. Hasil dari statistik deskriptif tersebut dapat dilihat pada Tabel 4 sebagai berikut.

Tabel 4.

Hasil Analisis Statistik Deskriptif

\begin{tabular}{lccccc}
\hline \multicolumn{1}{c}{ Variabel } & N & Min & Max & Mean & Std.Deviation \\
\hline Kualitas Pelayanan (X1) & 144 & 42 & 66 & 55,47 & 5,845 \\
Kewajiban Moral (X2) & 144 & 7 & 12 & 10,46 & 1,428 \\
Sanksi Pajak (X3) & 144 & 8 & 16 & 12,50 & 1,730 \\
Penerapan Alat Perekam Transaksi & 144 & 6 & 12 & 9,99 & 1,491 \\
(Tapping Box) (X4) & & 12 & 20 & 17,56 & 2,569 \\
Kepatuhan Wajib Pajak Hotel (Y) & 144 & & & & \\
Valid N (listwise) & & & &
\end{tabular}

Sumber: Data diolah, 2018

Berdasarkan Tabel 4 menunjukkan hasil statistik deskriptif yang meliputi nilai minimum, nilai maksimun, nilai rata-rata (mean) dan standar deviasi dari masing-masing variabel penelitian dengan jumlah pengamatan $(\mathrm{N})$ penelitian ini berjumlah 144 .

Variabel kualitas pelayanan $\left(\mathrm{X}_{1}\right)$ memiliki nilai minimum sebesar 42 dan nilai maksimum sebesar 66 dengan nilai rata-rata sebesar 55,47 yang apabila dibagi dengan 5 item pernyataan akan menghasilkan nilai sebesar 3,26. Hal ini berarti rata-rata responden memberikan skor 3 pada setiap item pernyataan 
variabel kualitas pelayanan. Standar deviasi pada variabel ini sebesar 5,845 yang menunjukkan bahwa standar penyimpangan data terhadap nilai rata-ratanya adalah 5,845.

Variabel kewajiban moral $\left(\mathrm{X}_{2}\right)$ memiliki nilai minimum sebesar 7 dan nilai maksimum sebesar 12 dengan nilai rata-rata sebesar 10,46 yang apabila dibagi dengan 3 item pernyataan akan menghasilkan nilai sebesar 3,49. Hal ini berarti rata-rata responden memberikan skor 3 pada setiap item pernyataan variabel kewajiban moral. Standar deviasi pada variabel ini sebesar yang1,428 menunjukkan bahwa standar penyimpangan data terhadap nilai rata-ratanya adalah 1,428 .

Variabel sanksi pajak $\left(\mathrm{X}_{3}\right)$ memiliki nilai minimum sebesar 8 dan nilai maksimum sebesar 16 dengan nilai rata-rata sebesar 12,50 yang apabila dibagi dengan 4 item pernyataan akan menghasilkan nilai sebesar 3,13. Hal ini berarti rata-rata responden memberikan skor 3 pada setiap item pernyataan variabel sanksi pajak. Standar deviasi pada variabel ini sebesar yang1,730 menunjukkan bahwa standar penyimpangan data terhadap nilai rata-ratanya adalah 1,730.

Variabel penerapan alat perekam transaksi (Tapping Box) $\left(\mathrm{X}_{4}\right)$ memiliki nilai minimum sebesar 6 dan nilai maksimum sebesar 12 dengan nilai rata-rata sebesar 9,99 yang apabila dibagi dengan 3 item pernyataan akan menghasilkan nilai sebesar 3,33. Hal ini berarti rata-rata responden memberikan skor 3 pada setiap item pernyataan variabel penerapan alat perekam transaksi (Tapping Box). Standar deviasi pada variabel ini sebesar yang1,491 menunjukkan bahwa standar penyimpangan data terhadap nilai rata-ratanya adalah 1,491. 
Ni Putu Mitha Pratiwi dan Ni Ketut Lely Aryani. Pengaruh...

Variabel kepatuhan wajib pajak hotel (Y) memiliki nilai minimum sebesar 12 dan nilai maksimum sebesar 20 dengan nilai rata-rata sebesar 17,56 yang apabila dibagi dengan 5 item pernyataan akan menghasilkan nilai sebesar 3,51. Hal ini berarti rata-rata responden memberikan skor 3 pada setiap item pernyataan variabel penerapan alat perekam transaksi (Tapping Box). Standar deviasi pada variabel ini sebesar yang2,569 menunjukkan bahwa standar penyimpangan data terhadap nilai rata-ratanya adalah 2,569 .

Analisis regresi linear berganda merupakan analisis yang digunakan untuk mengetahui pengaruh dua atau lebih variabel independen $(\mathrm{X})$ pada suatu variabel dependen (Y). Hasil uji regresi liner berganda terhadap empat variabel yakni kualitas pelayanan $\left(\mathrm{X}_{1}\right)$, kewajiban moral $\left(\mathrm{X}_{2}\right)$, sanksi pajak $\left(\mathrm{X}_{3}\right)$, penerapan alat perekam transaksi (Tapping Box) $\left(\mathrm{X}_{4}\right)$. Hasil uji analisis regresi linear berganda disajikan pada Tabel 5 sebagai berikut.

Tabel 5.

Hasil Uji Analisis Regresi Linear Berganda

\begin{tabular}{|c|c|c|c|c|c|}
\hline \multirow[b]{2}{*}{ Variabel } & \multicolumn{2}{|c|}{$\begin{array}{c}\text { Unstandardized } \\
\text { Coefficient }\end{array}$} & \multirow{2}{*}{$\begin{array}{c}\begin{array}{c}\text { Standardized } \\
\text { Coefficient }\end{array} \\
\text { Beta }\end{array}$} & \multirow[b]{2}{*}{$\mathbf{T}$} & \multirow[b]{2}{*}{ Sig. } \\
\hline & B & $\begin{array}{l}\text { Std. } \\
\text { Error }\end{array}$ & & & \\
\hline (Constant) & $-0,616$ & 1,294 & & $-0,476$ & 0,635 \\
\hline Kualitas Pelayanan (X1) & 0,104 & 0,042 & 0,236 & 2,487 & 0,014 \\
\hline Kewajiban Moral (X2) & 0,442 & 0,142 & 0,246 & 3,109 & 0,002 \\
\hline Sanksi Pajak (X3) & 0,245 & 0,119 & 0,165 & 2,069 & 0,040 \\
\hline $\begin{array}{l}\text { Penerapan Alat Perekam } \\
\text { Transaksi (Tapping Box) (X4) }\end{array}$ & 0,473 & 0,120 & 0,275 & 3,949 & 0,000 \\
\hline Adjusted $\mathrm{R}^{2}$ & & & & & 0,606 \\
\hline $\mathrm{F}$ & & & & & 55,958 \\
\hline Sig. F & & & & & 0,000 \\
\hline
\end{tabular}

Tabel 5 menunjukkan nilai koefisien regresi dari variabel bebas yakni kualitas pelayanan $\left(\mathrm{X}_{1}\right)$, kewajiban moral $\left(\mathrm{X}_{2}\right)$, sanksi pajak $\left(\mathrm{X}_{3}\right)$, penerapan alat 
perekam transaksi (Tapping Box) $\left(\mathrm{X}_{4}\right)$ dan variabel terikat yakni dan kepatuhan wajib pajak hotel (Y), maka persamaan regresi linear berganda yang dapat disusun sebagai berikut.

$$
Y=-0,616+0,104\left(X_{1}\right)+0,442\left(X_{2}\right)+0,245\left(X_{3}\right)+0,473\left(X_{4}\right)
$$

Nilai konstanta sebesar $-0,616$ berarti variabelkualitas pelayanan $\left(\mathrm{X}_{1}\right)$, kewajiban moral $\left(\mathrm{X}_{2}\right)$, sanksi pajak $\left(\mathrm{X}_{3}\right)$, penerapan alat perekam transaksi (Tapping Box) $\left(\mathrm{X}_{4}\right)$ dianggap konstan pada angka 0 (nol), maka kepatuhan wajib pajak hotel (Y) dapat diartikan menurun sebesar -0,616.

Nilai koefisien regresi $\beta_{1}$ sebesar 0,104 menjelaskan bahwa apabila kualitas pelayanan $\left(\mathrm{X}_{1}\right)$ meningkat satu satuan, maka nilai kepatuhan wajib pajak hotel (Y) akan mengalami peningkatan sebesar 0,104dengan asumsi variabel lain dianggap konstan.

Nilai koefisien regresi $\beta_{2}$ sebesar 0,442 menjelaskan bahwa apabila kewajiban moral $\left(\mathrm{X}_{2}\right)$ meningkat satu satuan, maka nilai kepatuhan wajib pajak hotel (Y) akan mengalami peningkatan sebesar 0,442 dengan asumsi variabel lain dianggap konstan.

Nilai koefisien regresi $\beta_{3}$ sebesar 0,245 menjelaskan bahwa apabila sanksi pajak $\left(\mathrm{X}_{3}\right)$ meningkat satu satuan, maka nilai kepatuhan wajib pajak hotel (Y) akan mengalami peningkatan sebesar 0,245 dengan asumsi variabel lain dianggap konstan.

Nilai koefisien regresi $\beta_{4}$ sebesar 0,473 menjelaskan bahwa apabila penerapan alat perekam transaksi (Tapping Box) $\left(\mathrm{X}_{4}\right)$ meningkat satu satuan, 
Ni Putu Mitha Pratiwi dan Ni Ketut Lely Aryani. Pengaruh...

maka nilai kepatuhan wajib pajak hotel (Y) akan mengalami peningkatan sebesar 0,473 dengan asumsi variabel lain dianggap konstan.

Koefisien determinasi digunakan untuk mengukur sejauh mana kemampuan variabel independen dalam menerangkan variasi variabel dependen. Berdasarkan Tabel 5 menunjukkan nilai Adjusted $\mathrm{R}^{2}$ sebesar 0,606 yang memiliki arti $60,06 \%$ variasi kepatuhan wajib pajak hotel (Y) dipengaruhi olehkualitas pelayanan $\left(\mathrm{X}_{1}\right)$, kewajiban moral $\left(\mathrm{X}_{2}\right)$, sanksi pajak $\left(\mathrm{X}_{3}\right)$, penerapan alat perekam transaksi (Tapping Box) $\left(\mathrm{X}_{4}\right)$, sedangkan $39.94 \%$ dipengaruhi oleh faktor-faktor lain yang tidak dimasukkan dalam model penelitian.

Berdasarkan Tabel 5 menunjukkan nilai signifikansi sebesar 0,000 lebih kecil dari 0,05. Hal ini menunjukkan bahwa seluruh variabel independen mampu menjelaskan fenomena dari variabel dependen, sehingga dapat disimpulkan bahwa model dalam penelitian ini layak digunakan (fit).

Uji hipotesis Pengaruh Kualitas pelayanan $\left(\mathrm{X}_{1}\right)$ terhadap kepatuhan wajib pajak dalam membayar pajak hotel di Badan Pengelolaan Keuangan dan Aset Daerah Kabupaten Gianyar. Tabel 5 hasil analisis Pengaruh Kualitas pelayanan terhadap kepatuhan wajib pajak dalam membayar pajak hotel di Badan Pengelolaan Keuangan dan Aset Daerah Kabupaten Gianyar diperoleh nilai sig.t sebesar 0,014 dengan nilai koefisien beta 0,104. Nilai sig. t 0,014<0,05 mengindikasikan bahwa kualitas pelayanan berpengaruh positif pada kepatuhan wajib pajak dalam membayar pajak hotel di Badan Pengelolaan Keuangan dan Aset Daerah Kabupaten Gianyar. 
Hasil Penelitian ini memperkuat teori Theory of Planned Behavior, yaitu Behavior Beliefs mengenai keyakinan individu akan hasil dari suatu perilaku dan evaluasi dari suatu perilaku wajib pajak dapat dipengaruhi adanya kualitas pelayanan. Kemauan wajib pajak hotel untuk membayar pajak sebagian besar di pengaruhi oleh kulitas pelayanan yang diberikan oleh pemerintah.Hasil Penelitian sejalan dengan hasil penelitian sebelumnya yang dilakukan oleh (Sucandra \& Supadmi, 2016) Wajib pajak yang mendapatkan pelayanan dengankualitas yang baik akan senantiasa merasa senang, merasa puas atas pemberian pelayanan yang diberikan petugas pajak karena wajib pajak dapat memperoleh kemudahan dalam menyelesaikan dan melaksanakan seluruh hak dan kewajibannya sebagai wajib pajak sehingga kepatuhan wajib pajak dalam memenuhi kewajibannya meningkat.

Uji hipotesis pengaruh kewajiban moral $\left(\mathrm{X}_{2}\right)$ pada kepatuhan wajib pajak hotel. Tabel 5 hasil analisis pengaruh kewajiban moral pada kepatuhan wajib pajak hotel memeroleh nilai sig.t sebesar 0,002 dengan nilai koefisien beta 0,442 . Nilai sig. t 0,002 <0,05 mengindkasikan bahwa kewajiban moral berpengaruh positif pada kepatuhan wajib pajak dalam membayar pajak hotel di Badan Pengelolaan Keuangan dan Aset Daerah Kabupaten Gianyar.

Hasil Penelitian ini memperkuat teori legitimasi yang menyatakan bahwa tanggung jawab moral yang baik dari wajib pajak hotel merupakan salah satu cara untuk meningkatkan legitimasi wajib pajak hotel dalam hal ini wajib pajak hotel pada Badan Pengelolaan Keuangan dan Aset Daerah Kabupaten Gianyar untuk patuh dalam melaporakan pajaknya. Penelitian ini juga memperkuat penelitian (Akib et al., 2017) bahwa tanggung jawab moral berpengaruh positif dan 
Ni Putu Mitha Pratiwi dan Ni Ketut Lely Aryani. Pengaruh...

signifikan terhadap kepatuhan pelaporan wajib pajakbadan. Hal ini menunjukkan bahwa tanggung jawab moral dapat mendorong tingkatkepatuhan pelaporan wajib pajak badan. Semakin baik tanggung jawab moral seseorang maka semakin meningkat pula tingkat kepatuhan seseorang dalam memenuhi kewajiban perpajakkannya. Penelitian ini sejalan dengan penelitian (Putri \& Jati, 2015), (Layata \& Setiawan, 2014) dan (Indrayani \& Sukartha, 2014) mendukung hasil penelitian ini yang menyatakan bahwa kewajiban moral berpengaruh positif pada kepatuhan wajib pajak dalam membayar pajak.

Tabel 5 hasil analisis pengaruh sanksi perpajakan pada kepatuhan wajib pajak hotel memperoleh nilai sig.t sebesar 0,040 dengan nilai koefisien beta 0,245. Nilai sig. t 0,040<0,05 mengindkasikan bahwa sanksi pajak berpengaruh positif pada kepatuhan wajib pajak dalam membayar pajak hotel di Badan Pengelolaan Keuangan dan Aset Daerah Kabupaten Gianyar.

Penelitian ini memperkuat teori legitimasi yang menyatakan bahwa ketidakselarasan yang terjadi akan menyebabkan adanya tuntutan dari wajib pajak hotel yang menimbulkan pemberontakan dan hilangnya legitimasi. Sanksi pajak merupakan alat pencegah (preventif) agar wajib pajak hotel tidak melanggar norma perpajakan sehingga legitimasi wajib pajak di Badan Pengelolaan Keuangan dan Aset Daerah Kabupaten Gianyar dapat terjaga. Penelitian ini memperkuat penelitian ( Dewi \& Merkusiwati, 2018) menyatakan bahwa Sanksi perpajakan berpengaruh postif terhadap kepatuhan pelaporan wajib pajak. Artinya semakin tegas sanksi yang diberikan akan membuat wajib pajak tersebut semakin patuh untuk memenuhi kewajiban perpajakannya. Penelitian ini sejalan dengan 
penelitian (Dewi \& Merkusiwati, 2018) mendukung hasil penelitian ini yang menyatakan bahwa sanksi berpengaruh positif pada kepatuhan wajib pajak.

Uji Hipotesis pengaruh penerapan alat perekam transaksi (Tapping Box) $\left(\mathrm{X}_{4}\right)$ pada kepatuhan wajib pajak hotel. Tabel 5 menunjukkan nilai sig.t sebesar 0,000 dengan nilai koefisien beta 0,0473 . nilai sig $\mathrm{t} 0,000<0,05$ mengindikasikan bahwa mengindkasikan bahwa penerapan alat perekam transaksi (Tapping Box) berpengaruh positif pada kepatuhan wajib pajak dalam membayar pajak hotel di Badan Pengelolaan Keuangan dan Aset Daerah Kabupaten Gianyar.

Hasil Penelitian ini memperkuat Theory Planned of Behavior yaitu Control Beliefs yang merupakan keyakinan individu tentang keberadaan hal-hal yang mendukung atau menghambat perilakunya dan persepsinya tentang seberapa kuat hal-hal tersebut memengaruhinya. Penelitian ini memperkuat penelitian (Pramasita \& Resmini, 2018) menyatakan bahwa penerapan alat perekam transaksi sangat efektif dalam mengurangi terjadinya kecurangan terhadap pelaporan pajak. Karena Tapping Boxmampu memberikan gambaran lebih detail terhadap jumlah pajak yang harus dibayarkan oleh wajib pajak akan berdampak signifikan terhadap penerimaan pajak daerah. Penerapan Tapping Boxakan meningkatkan kepatuhan wajib pajak dalam membayar pajak.

Rendahnya tingkat kepatuhan wajib pajak adalah faktor yang memengaruhi penerimaan pajak. Untuk meningkatkan penerimaan Negara melalui sektor pajak, dibutuhkan partisipasi dari wajib pajak itu sendiri untuk memenuhi segala kewajiban pajaknya. Artinya peningkatan penerimaan Negara ditentukan oleh 
Ni Putu Mitha Pratiwi dan Ni Ketut Lely Aryani. Pengaruh...

tingkat kepatuhan wajib pajak. Hasil penelitian ini menunjukkan bahwa kualitas pelayanan, kewajiban moral, sanksi pajak, dan penerapan alat perekam transaksi (Tapping Box) sangat memengaruhi tingkat kepatuhan wajib pajak. Oleh karena itu, sebaiknya faktor-faktor ini perlu diperhatikan agar kedepannya tingkat kepatuhan wajib pajak dalam memenuhi kewajiban perpajakannya semakin tinggi. Selain itu hasil penelitian ini juga dapat menambah wawasan dan pengetahuan mengenai tingkat kepatuhan wajib pajak dalam membayar pajak hotel serta dapat digunakan sebagai referensi bagi penelitian selanjutnya.

Berdasarkan hasil penelitian ini dapat diketahui bahwa kualitas pelayanan, kewajiban moral, sanksi pajak, dan penerapan alat perekam transaksi (Tapping Box) berpengaruh terhadap kepatuhan wajib pajak dalam membayar pajak hotel di Badan Pengelolaan Keuangan dan Aset Daerah Kabupaten Gianyar. Berkaitan dengan hal itu diharapkan bagi pihak instansi khususnya Badan Pengelolaan Keuangan dan Aset Daerah Kabupaten Gianyar untuk dapat lebih meningkatkan kesadaran akan kualitas pelayanan, kewajiban moral, sanksi pajak, dan penerapan alat perekam transaksi (Tapping Box), karena hal tersebut dapat meningkatkan kepatuhan wajib pajak dalam membayar pajak hotel di Badan Pengelolaan Keuangan dan Aset Daerah Kabupaten Gianyar, sehingga pelaporan oleh wajib pajak akan efektif dan pendapatan pajak khususnya pajak hotel akan meningkat sehingga dapat mencapai target. 


\section{SIMPULAN}

Kualitas pelayanan berpengaruh positif pada kepatuhan wajib pajak dalam membayar pajak hotel di Badan Pengelolaan Keuangan dan Aset Daerah Kabupaten Gianyar. Semakin baik kualitas pelayanan yang diberikan oleh petugas pajak kepada wajib pajak semakin tinggi pula tingkat kepatuhan wajib pajak dalam membayar pajak di Badan Pengelolaan Keuangan dan Aset Daerah Kabupaten Gianyar

Kewajiban moral berpengaruh positif pada kepatuhan wajib pajak dalam membayar pajak hotel di Badan Pengelolaan Keuangan dan Aset Daerah Kabupaten Gianyar. Semakin tinggi kewajiban moral yang dimiliki oleh setiap wajib pajak hotel maka semakin tinggi pula tingkat kepatuhan wajib pajak dalam membayar kewajiban pajaknya di Badan Pengelolaan Keuangan dan Aset Daerah Kabupaten Gianyar.

Sanksi pajak berpengaruh positif pada kepatuhan wajib pajak dalam membayar pajak hotel di Badan Pengelolaan Keuangan dan Aset Daerah Kabupaten Gianyar. Semakin tegas sanksi perpajakan yang dikenakan bagi wajib pajak hotel yang terlambat atau tidak melaksanakan kewajiban pajaknya, maka akan semakin tinggi pula kepatuhan wajib pajak hotel dalam memenuhi kewajiban perpajakannya di Badan Pengelolaan Keuangan dan Aset Daerah Kabupaten Gianyar.

Penerapan alat perekam transaksi (Tapping Box) berpengaruh positif pada kepatuhan wajib pajak dalam membayar pajak hotel di Badan Pengelolaan Keuangan dan Aset Daerah Kabupaten Gianyar. Jika, penerapan tapping box 
Ni Putu Mitha Pratiwi dan Ni Ketut Lely Aryani. Pengaruh...

dapat memudahkan, dan memberikan manfaat bagi wajib pajak hotel, maka akan semakin tinggi pula kepatuhan wajib pajak hotel dalam memenuhi kewajiban perpajakannya di Badan Pengelolaan Keuangan dan Aset Daerah Kabupaten Gianyar.

Bagi peneliti selanjutnya yang tertarik untuk melakukan kajian di bidang yang sama dapat menambah variabel independen maupun dependen yang memiliki kemungkinan pengaruh terhadap hubungan kualitas pelayanan, kewajiban moral, sanksi pajak dan penerapan alat perekam transaksi (Tapping Box) atau dapat menggunakan variabel-variabel yang tidak digunakan dalam penelitian ini, dan bisa meneliti dampak bagi kepatuhan wajib pajak hotel sesudan dan sebelum dipasangkan alat perekam transaksi (Tapping Box) sehingga dapat ditemukan variabel baru yang akan meningkatkan kepatuhan wajib pajak.

\section{REFERENSI}

Akib, M., Sari, I. M., \& Asnia, A. (2017). Pengaruh Tanggung Jawab Moral Dan Kualitas Pelayanan Terhadap Kepatuhan Pelaporan Wajib Pajak Badan (Studi pada Kantor Pelayanan Pajak Pratama Kendari). Jurnal akuntansi dan $\begin{array}{llll}\text { keuangan, } & 2 & \text { (2). } & \text { Retrieved }\end{array}$ http://ojs.uho.ac.id/index.php/Jurnalakuntansikeuangan/article/view/2981.

Anggraini, R. (2012). Pengaruh Pengetahuan Pajak, Persepsi Tentang Petugas Pajak dan Sistem Administrasi Pajak Terhadap Tingkat Kepatuhan Wajib Pajak Orang Pribadi. Artikel Ilmiah, 5(2).

Boonyarat, N., Sofian, S., \& Wadeecharoen, W. (2015). The antecedents of taxpayers compliance behavior and effectiveness of Thai local government levied tax. International Business Management, 10(1), 23-39. https://doi.org/10.3923/ibm.2015.431.439.

Chritina, N. K., \& Kepramareni, putu. (2012). Pengaruh Kewajiban Moral, Kualitas Pelayanan dan Sanksi Perpajakan Pada Kepatuhan Wajib Pajak Dalam Membayar Pajak Kendaraan Bermotor Di Kantor Bersama Samsat 
Denpasar. Jurnal Riset Akuntansi Dan Keuangan, 2(2).

Daniel, D., \& Wong, B. (2012). Issues on compliance and ethics in taxation: what do we know? Journal of Financial Crime, 15(4), 369-382. https://doi.org/10.1108/13590790810907218.

Devos, K., \& Zackrisson, M. (2015). Tax compliance and the public disclosure of tax information: An Australia/Norway comparison. EJournal of Tax Research.

Dewi, G. A. P. I. P., \& Merkusiwati, N. K. L. A. (2018). Faktor-Fator yang Memengaruhi Tingkat Kepatuhan Wajib Pajak Orang Pribadi di KPP Pratama Badung Utara. E-Jurnal Akuntansi, 23(2), 1277. https://doi.org/10.24843/EJA.2018.v23.i02.p18.

Dewi, L. P. S. K., \& Merkusiwati, N. K. L. A. (2018). Pengaruh Kesadaran Wajib Pajak, Sanksi Perpajakan, E-Filing , dan Tax Amnesty Terhadap Kepatuhan Pelaporan Wajib Pajak. E-Jurnal Akuntansi Universitas Udayana, 22(2), 1626-1655. https://doi.org/https://doi.org/10.24843/EJA.2018.v22.i02.p30.

Dewi, P. S., \& Sukartha, I. M. (2015). Faktor_Faktor Yang Mempengaruhi Kepatuhan Wajib Pajak Dalam Membayar Pajak Hotel. E-Jurnal Akuntansi Universitas Udayana, 13(2), 599-614.

Indrayani, P. A., \& Sukartha, I. M. (2014). No Title. Tanggung Jawab Moral, Kesadaran Wajib Pajak, Sanksi Perpajakan Dan Kualitas Pelayanan Pada Kepatuhan Pelaporan Wajib Pajak Badan, 7(2), 431-443.

James, R. S., \& Nobes, C. W. (1997). The Economics of Taxation - Principles, Policy and Parctice.

jaya, ida bagus meindra, \& Jati, I. K. (2016). Pengaruh kesadaran, kualitas pelayanan, pemeriksaan dan sanksi perpajakan pada kepatuhan wajib pajak restoran. E- Jurnal Akuntansi Universitas Udayana, 16(1), 471-500.

Juliantara, I. G. R., \& Setiawan, P. E. (2017). Kemudahan pengisian spt, pengetahuan perpajakan, kualitas pelayanan pada kepatuhan wpop di kpp pratama denpasar timur. E- Jurnal Akuntansi Universitas Udayana, 20(3), $1734-1761$.

Retrieved

from https://ojs.unud.ac.id/index.php/Akuntansi/article/view/26335

Layata, S., \& Setiawan, P. E. (2014). Pengaruh kewajiban moral, kualitas pelayanan, pemeriksaan pajak dan sanksi perpajakan pada kepatuhan wajib pajak badan. E- Jurnal Akuntansi Universitas Udayana, 9(2), 540-556.

Mentari, D., \& Rahayu, S. (2015). Efektivitas Dan Kontribusi Penerimaan Pajak 
Hotel Dan Pajak Restoran Terhadap Pendapatan Asli Daerah Kota Bandung Tahun 2009-2013. EProceedings of Management, 2(2). Retrieved from https://libraryeproceeding.telkomuniversity.ac.id/index.php/management/arti cle/view/527

Mulyati Akib, Ika Maya Sari, A. (2017). Pengaruh tanggung jawab moral dan kualitas pelayanan terhadap kepatuhan pelaporan wajib pajak badan (Studi pada Kantor Pelayanan Pajak Pratama Kendari). UHO Jurnal Akuntansi Dan Keuangan Fakultas Ekonomi Dan Bisnis, 2(2), 73-85.

Nirajenani, C. I. P., \& Merkusiwati, N. K. L. A. (2018). Faktor-faktor yang Mempengaruhi Kepatuhan Wajib Pajak dalam Membayar Pajak Kendaraan Bermotor. E- Jurnal Akuntansi Universitas Udayana, 24(1), 339-369. https://doi.org/https://doi.org/10.24843/EJA.2018.v24.i01.p13

Pramasita, I. A., \& Resmini, N. K. (2018). Pengaruh Kesadaran Wajib Pajak, Pengetahuan Pajak, Kualitas Pelayanan, dan Penerapan Alat Perekam Transaksi (Tapping Box) Pada kepatuhan Wajib Pajak Dalam Membayar Pajak Hotel di Badan Pendapatan Kota Denpasar. E- Jurnal Akuntansi Universitas Udayana, 5(1), 456-468.

Pranata, P. A., \& Setiawan, P. E. (2015). Pengaruh Sanksi Perpajakan, Kualitas Pelayanan dan Kewajiban Moral pada Kepatuhan Wajib Pajak. E-Jurnal Akuntansi Universitas Udayana, 10(2), 456-473. https://doi.org/10.1152/japplphysiol.01164.2001

Pratiwi, I. G. A. M. A. M. A., \& Setiawan, P. E. (2014). Efektifitas pemungutan pajak reklame dan kontribusinya terhadap penerimaan pajak daerah di kota bandung. E- Jurnal Akuntansi Universitas Udayana, 6(1), 139-153.

Putra, I. G. A. S. M., \& Merkusiwati, N. K. L. A. (2018). Faktor - Faktor yang Mempengaruhi Kepatuhan Wajib Pajak Kendaraan Bermotor di Kabupaten Gianyar, $23 \quad$ (1), 461-488. https://doi.org/https://doi.org/10.24843/EJA.2018.v23.i01.p18.

Putri, A. R. S., \& Jati, I. K. (2015). Faktor-faktor yang mempengaruhi kepatuhan wajib pajak dalam membayar pajak kendaraan bermotor di denpasar, (2011), 661-677. https://doi.org/10.1017/CBO9781107415324.004.

Sucahyani, N. M. A., \& Sukartha, I. M. (2017). Pengaruh pengetahuan, pelayanan, biaya kepatuhan, dan sanksi pada kepatuhan wajib pajak dalam membayar pajak hotel. E- Jurnal Akuntansi Universitas Udayana, 20 (1), 231-260.

Sucandra, I. P., \& Supadmi, N. L. (2016). Pengaruh kualitas pelayanan, pemeriksaan pajak, pengetahuan perpajakan dan sanksi perpajakan pada 
kepatuhan wajib pajak restoran. E- Jurnal Akuntansi Universitas Udayana, 16(2), 1210-1237. Retrieved from https://ojs.unud.ac.id/index.php/Akuntansi/article/view/17610

Susilawati, K. E., \& Budiartha, K. (2013). Pengaruh Kesadaran Wajib Pajak, Pengetahuan Pajak, Sanksi Perpajak, dan Akuntabilitas Pelayanan Publik Pada Kepatuahan Wajib Pajak Kendaraan Bermotor. E- Jurnal Akuntansi Universitas Udayana, 4(2)(2), 345-357.

Torgler, B. (2005). Tax morale and direct democracy. European Journal of Political Economy. https://doi.org/10.1016/j.ejpoleco.2004.08.002

Undang-Undang Nomor 2 Tahun 2011 Tentang Pajak Hotel Kabupaten Gianyar. (n.d.).

Retrieved from https://jdih.gianyarkab.go.id/storage/app/uploads/public/5a5/dd2/d62/5a5dd6 2fc73636686900.pdf.

Undang-Undang nomor 28 Tahun 2009 Tentang Pajak Daerah dan Retribusi Daerah. (n.d.). Retrieved from http://www.djpk.depkeu.go.id/attach/post-no28-tahun-2009-tentang-pajak-daerah-dan-retribusi-daerah/UU-427-973UU_28_Tahun_2009_Ttg_PDRD.pdf.

Yasa, I. P. R. P., \& Jati, I. K. (2017). Kondisi keuangan wajib pajak pemoderasi pengaruh sanksi perpajakan, kesadaran wajib pajak pada kepatuhan wajib pajak. E- Jurnal Akuntansi Universitas Udayana, 19(2), 1521-1550. 